Proceedings of the 2018 International Scientific Conference 'Economic Sciences for Agribusiness and Rural Economy' No 2, Warsaw, 7-8 June 2018, pp. 300-305

\title{
SOCIAL CAPITAL IN THE COMPANY (MEAT AND VEGETABLE PROCESSING INDUSTRY)
}

\author{
Elżbieta Jędrych, $\mathrm{PhD}^{1}$; Dariusz Klimek, $\mathrm{PhD}^{2}$ \\ ${ }^{1}$ Faculty of Business and International Relations, Vistula University \\ ${ }^{2}$ Faculty of Management and Production Engineering, Lodz University of Technology
}

\begin{abstract}
This article presents the research results of authors on the structure and value of social capital in the company. The research shows that there is a link between a relatively new level of such capital obtained on the basis of questionnaires among company employees analysed and the low value of this capital in the socio-economic approach. The authors also point out the possible ways of improving this level and increasing its financial value. The research was conducted in the first half of 2018, in Pamapol, a joint-stock company, which is one of the biggest companies from the branch of meat and food processing. In the research, the triangulation method of research methods was used, already known in research practice but in an innovative character, mainly referring to the measurement of capital value.
\end{abstract}

Key words: social capital, structure of social capital, value of social capital

JEL codes: E22, G32, J24, O34

\section{INTRODUCTION}

In recent years social capital has become one of the major issues in social and economic sciences and in the business practice of many countries. It is considered to be a factor which significantly supports social and economic development; its quality explains economic successes and failures, innovativeness and competitiveness. Research conducted in Poland point at a deficit of social capital, both on a macro (society) and micro (economic organisations) scale. On international lists examining the indexes of social capital, Poland is placed at the very end of European countries - such a low level of social capital should be of concern. Many researchers and economic experts think that, in the last 30 years, human capital and financial capital was the motor for development - it is a feature of poor countries. However, after reaching a certain level of wealth, social capital becomes more and more important. In the opinion of experts, Poland is at the beginning of such a reality in which low social capital will enable quick economic growth. This regularity refers both to the development of society and business (Czapiński and Panek, 2015).

In Poland, social capital on a micro scale (in organisations) is hardly ever analysed. The results of research on the perception of negative consequences of a lack of social capital within companies, which

\footnotetext{
${ }^{1}$ Corresponding author: 3 Stokłosy, 02-787 Warsaw, Poland, e.jedrych@vistula.edu.pl, +48 602631009

${ }^{2}$ Corresponding author: 266 Piotrkowska, 90-924 Lodz, Poland, dariusz.klimek@p.lodz.pl, +48 602300590
} 
have been published recently, show that this problem is slowly but surely being recognised by managers and business leaders (Będzik, 2010; Dobrowolski, 2015). The research which refers to this topic in the food branch are exceptional (Gajowiak, 2013).

The authors of this paper present the results of the newest research in this area, conducted in the first half of 2018, in a few companies of different branches and sizes, taking into consideration the conference topic and length of the article for presentation. The results obtained in the company Pamapol which is a joint-stock company with headquarters in Rusiec were selected.

\section{ESSENCE OF SOCIAL CAPITAL}

Social capital is defined as a resource of individuals, groups and societies formed by a network of social relations, norms and values which regulate them and enable to achieve the effects of cooperation. Trust among people forms the basis of social capital. The practical sense of social capital lies in 'catching' the values present in the resources of relations among people leading to an increase in the effectiveness of using different capital (e.g. in the company this constitutes human capital, real capital, structural capital and market capital). Social capital, therefore, is a kind of connection of societies that forms a totality facilitating effective and efficient cooperation based on trust.

Although the term social capital was first used more than a hundred years ago by Hanifan (1916), the first systemic analysis of the notion of social capital was only conducted by Bourdieu. He defined social capital as a sum of resources, both current and potential ones, which should belong to an individual or a group because of possessing a durable, more or less institutionalised network of relations, contacts and mutual recognition (Bourdieu and Wacquant, 2001). Another classic, Coleman is the author of the definition considered to be basic for the total, systematic presentation of social capital defined as an economic perspective (a theory of rational activity). The essence of social capital, according to Coleman, can be put down to capacity of people to cooperate within groups and organisations. Putman - another classic in this field - defined social capital as the properties of social life - networks, norms and trust which facilitate cooperation and coordination in order to gain mutual benefits (Putnam, 1997). He considered trust to be the most important element of social capital. However, he understood trust differently than Coleman - not as a feature of individuals meaning 'being trustworthy' but as a non-defined 'climate of cooperation' understood as social trust.

Social capital is considered to be a motor for well developed economies; economists estimate that it determines speed of growth by 53\%. The strength of social capital lies in the fact that it is based on trust which facilitates negotiations, decreases transaction costs, is favourable for knowledge flow, increases the engagement and entrepreneurship of people, solidarity among the groups and prevents the abuse of common welfare.

A strong, positive link between social capital and social welfare is very well empirically documented (Halpern, 2005; Bratnicki and Dyduch, 2003; Sztaudynger, Ambroziak and Starosta, 2016).

\section{SUBJECT AND RESEARCH METHODOLOGY}

Pamapol, a joint-stock company in Rusiec, is a viceleader of ready dishes in Poland. Its offer includes products from the category of ready dishes as well as meat conserves, pates, ready soups and canned vegetables sold both in traditional channels through wholesale and big commercial networks.

Pamapol is also a dominant company in the capital group including: Warmińskie Zakłady Przetwórstwa Owocowo-Warzywnego in Kwidzyn, ranked among leading domestic producers in this industry of peas and beans among others and Mitmar Sp. z o.o. with headquarters in Głowno, whose main activity is meat trade and the production of frozen ready dishes as well as providing storage and logistic services for frozen products produced in the Group and confectioning of frozen vegetable and vegetable-meat mixtures.

The aims of the first stage of research (research on the structure of capital) were as follows:

1. A definition of the level of social capital of employees including: employees in managerial positions, employees in administrative positions/ specialists and employees in production positions; 
2. A definition of strengths and weaknesses of social capital;

3. A recommendation of activities which aims to strengthen social capital.

Due to the multidimensional and interdisciplinary character of the notion 'social capital', it was of key importance to prepare a model (of elements) of social capital which defined a substantive scope of research and constituted a basis to build a research tool.

It was assumed that social capital of a company can be characterized by means of three dimensions:

1. A structural dimension (structural capital). This dimension describes social capital from the point of view of the organizational perspective of the company; a kind of an organisational structure favourable for cooperation of employees within units and between units, a kind of a communication system - employee access to information, necessary knowledge and attitudes of managers towards activities facilitating cooperation.

2. A relational dimension (relation capital). This dimension describes the quality of contacts between employees and the kind of contacts, trust, reliability as well as eagerness of employees to share knowledge and experience.

3. A cognitive dimension (cognitive capital). This dimension describes coherence between norms and values of employees and of the company; a common understanding of company problems; a usage of vocabulary comprehensive for everybody and so on.

In order to measure social capital, a multi-dimensional psychometric tool was used- a survey questionnaire consisting of 40 questions, including at- tributes and indicators adopted in the model. Such a construction of the survey allowed for the creation of aggregated indexes of social capital. The psychometric tool is a deliberately constructed scale which analyses attitudes characterised by good psychometric parameters (accuracy, reliability). While creating the scale, the method of summing up evaluations, created by Likert, was used. It meant the evaluation of every 40 statements according to a five-level scale, presenting different levels of acceptance and evaluation of a given statement where: 5 means 'I completely agree', 4 - 'I partially agree', 3 - 'I have no opinion', 2 - 'I do not completely agree', 1 - 'I completely disagree'.

In total, 147 employees participated in the research, that is $72 \%$ of all people employed in Pamapol joint-stock company, including 17 people in managerial positions, 49 in administrative positions and 81 in production positions.

The definition of the value of social capital was the aim of the second stage of the research. Two convictions were adopted here. The first one - the value of the company is the sum of the value of 5 capitals: material, financial, structural (organisational) and market, human and social. The second conviction - the value of social capital is the difference between the value of the whole company and four capitals (material, financial, structural, market and human). The second conviction was necessary due to existing ambiguity while defining capital. In this way it is possible to avoid potential accusations that some element of social capital was not included in the evaluation.

The knowledge of valuation methods for the entire company and other capitals is also obvious. How-

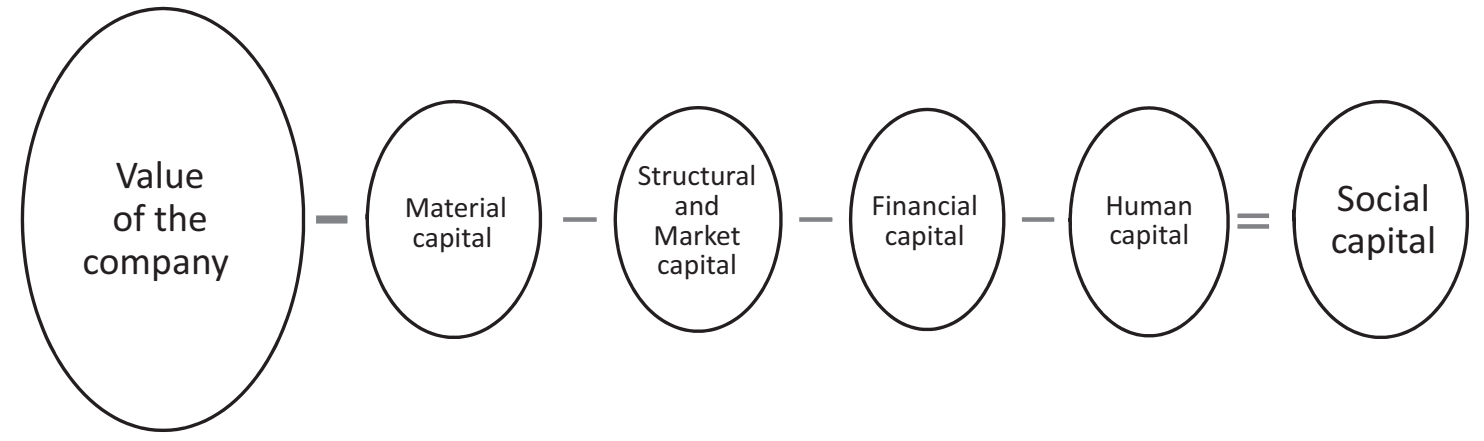

Figure 1. Diagram of the method of measuring the capital value of social capital Source: own elaboration. 
ever, it was not without a modification of valuation methods aimed at taking into account the 'utility' category for the organization and not 'marketability', especially in the evaluation of physical capital and general simplification of methods, that it would be possible to measure capital by company specialists without engaging external experts.

Certain difficulties also took place at the stage of allocating elements of organisations to different capitals, particularly to structural capital (organizational) and market capital.

The basic assumptions adopted for the evaluation of single capitals:

1. The evaluation of the value of the whole company using the DCF method (discounted cash flow) was done at a calculated discount level of 5.00. The estimation of the evaluation for the period 2018-2022 and the estimated money flows in these years formed the basis.

2. The evaluation of real capital was modified in such a way that for calculations the 'usability' coefficient of fixed assets in the company was assumed for calculation and not its 'marketability'.

3. The evaluation of structural capital was conducted on the basis of existing immaterial assets.

4. The evaluation of human capital was significantly simplified in comparison to the one applied in practice. Simplifying it, the value of this capital is expenditure on salaries or other labour costs e.g. trainings in the period necessary to obtain full knowledge and experience in a given position. Obviously, the human capital of a company is the sum of value in reference to all employees.

\section{RESULTS AND CONCLUSIONS}

The general overview of the level of social capital divided into groups of employees is presented in Table 1.

The general conclusions are as follows:

1. There is a big number of employees (in different positions) which are characterized by low social capital. This group is a potential reserve of social capital.

2. Simultaneously, there is a big group which possesses high social capital (engaged, with a skill to cooperate, with trust). This is the part of the team that the board can always count on - which constitutes real capital - formed by employees of different positions.

3. The biggest deficit of social capital is among employees in production positions (a frightening phenomenon in such an important group of employees).

The analysis of single dimensions/kinds of social capital shows some regularities presented in Table 2. In this case:

1. The analysis of single variations of social capital shows a low level of structural capital in all analysed groups (the way of the cooperation organization, access to information, knowledge flow, evaluations of managers according to criteria of organizing cooperation between employees of different departments).

2. The analysis of single indicators of social capital shows that the biggest deficit is visible in:

- The level of trust (particularly trust to superiors),

Table 1. The level of social capital in Pamapol joint-stock company according to groups of employees

\begin{tabular}{|l|c|c|}
\hline \multirow{2}{*}{ Employees of the company } & \multicolumn{2}{|c|}{ Level of social capital (\%) } \\
\cline { 2 - 3 } & high (very high, high) & low (very low, low) \\
\hline Total employees & 44.3 & 55.7 \\
\hline Managers & 49.3 & 50.7 \\
\hline Production employees & 40.6 & 59.4 \\
\hline Administration employees & 48.6 & 51.4 \\
\hline
\end{tabular}

Source: own collaboration. 
Proceedings of the 2018 International Scientific Conference 'Economic Sciences for Agribusiness and Rural Economy' No 2, Warsaw, 7-8 June 2018, pp. 300-305

Table 2. Levels of different kinds of social capital in Pamapol joint-stock company

\begin{tabular}{|l|c|c|}
\hline \multirow{2}{*}{ Dimension of social capital } & \multicolumn{2}{|c|}{ Level of social capital (\%) } \\
\cline { 2 - 3 } & High (very high, high) & Low (very low, low) \\
\hline Total employees & 44.3 & 55.7 \\
\hline Relational capital & 48.0 & 52.0 \\
\hline Cognitive capital & 43.3 & 56.7 \\
\hline Structural capital & 41.7 & 58.3 \\
\hline
\end{tabular}

Source: own collaboration.

- The level of relations between employees of different teams/ units/ departments,

- The level of voluntary activities of employees for the company (volunteering),

- The way of passing on values and norms of the company to employees.

The percentage shares of particular Pamapol capitals, including social capital, in the total value of the enterprise are presented in Table 3.

The final conclusions are as follows:

1. It is justified to evaluate the level of social capital in the company using the triangulation of methods referring both to the structure of this capital and its value. Only joint knowledge on structure and value provides the full image of this capital in the company and can constitute a basis for potential investment in this capital.

2. The single examination of the level and the value of social capital in the company in one year can, on the one hand, include mistakes and, on the other hand, does not allow to draw conclusions for the activities of the board to improve its level. Only the second examination conducted a year or two years later using (for comparison's sake) the same methods and convictions on the same or on a similar sample allows to evaluate whether applied recommendations for the increase of social capital were effective. Such research will allow to evaluate the influence of this capital on other capitals of the company.

3. Just as in case of typical economic indicators, practical knowledge on the level and value of social capital in the country and in branches will appear only when a lot of research in this field is conducted, which will create a point of reference and a comparison with the level and value of capital in other companies.

Table 3. The percentage shares of particular capitals in the value of Pamapol joint-stock company, as of March 2018

\begin{tabular}{|l|c|}
\hline Capitals & $\begin{array}{c}\text { Percentage share in the value of } \\
\text { Pamapol joint-stock company } \\
(\%)\end{array}$ \\
\hline Material capital & 40.9 \\
\hline Human capital & 27.3 \\
\hline Market capital & 17.7 \\
\hline Financial capital & 9.6 \\
\hline Social capital & 2.4 \\
\hline Structural capital & 2.1 \\
\hline Total & 100.0 \\
\hline
\end{tabular}

Source: own collaboration. 


\section{CONCLUSIONS}

In Poland, social capital on a micro scale (in organizations) is hardly ever examined.

The need for such research results, first of all, from the awareness that it is possible to invest in and multiply it. It also has a specific financial dimension. Investment in social capital is as necessary as in real, market or human capital. Managers need suitable tools which allow to define both the structure of this capital and its value.

The research presented here, as one of the first of this kind, and particularly the methodology applied, can be a starting point of critical discussion. The authors are aware of this and perceive the needs for further work in order to develop a research method for such a complicated phenomenon as social capital in the company.

\section{REFERENCES}

1. Będzik, B. (2010). Deficyt kapitału społecznego zwiastunem nadchodzących kłopotów [the social capital shortage as a herald of future troubles]. Acta Scientiarum Polonorum. Oeconomia., 9 (1), pp. 15-21.

2. Bourdieu, P., Wacquant, J. (2001). Zaproszenie do socjologii refleksyjnej [Invitation to reflexive sociology]. Seria TERMINUS. Vol. 21, Warszawa.

3. Bratnicki, M., Dyduch, W. (2003). W poszukiwaniu wyceny kapitału społecznego [In search of valuation of social capital]. Organizacja i Kierowanie, 1, pp. 3-15.
4. Coleman, J. (1990). Foundations of Social Theory. Harvard University Press, Cambridge.

5. Czapiński, J., Panek, T. (2015). Diagnoza Społeczna 2015 [Social Diagnosis 2015]. Rada Monitoringu Społecznego, Warszawa.

6. Dobrowolski, P. (2015). Raport: Polska drużyna. Kapitał społeczny w Polsce i dla Polski [Report: Polish team. Social capital in Poland and for Poland]. Związek Pracodawców Polskich, Warszawa.

7. Gajowiak, M. (2013). Kapitał społeczny w koncepcji organizacji inteligentnej na przykładzie MSP przetwórstwa żywnościowego z wybranych powiatów Wielkopolski [Social capital in the concept of intelligent organization on the example of MSP of food processing from selected poviats of Wielkopolska Region]. Optimum Studia Ekonomiczne, 4 (64), pp. 61-70.

8. Halpern, D. (2005). Silna korelacja między kapitałem społecznym a dynamiką wzrostu kapitału gospodarczego [Strong correlation between social capital and the dynamics of economic capital growth]. Social Capital. Polity Press Malden.

9. Hanifan, L.J. (1916). The Rural School Community Centre. Annals of the American Academy of Political and Social Sciences.

10. Putnam, R. (1997). Democracy in America at century's end. In: Hadenius, A (ed.) Democracy's Victory and Crisis. Cambridge University Press, Cambridge.

11. Sztaudynger, J., Ambroziak, E., Starosta, P. (2016). Zaufanie, skłonność do pomocy i uczciwość a wzrost gospodarczy w Europie [Trust, tendency to help and honesty and economic growth in Europe]. Ekonomista, 5, pp. 647-673. 